\title{
Putting the City on the World Art Map: Star Curators and Nation Branding
}

\author{
Jérémie Molho ${ }^{1}$ \\ Accepted: 25 September 2020 / Published online: 19 October 2020 \\ (C) The Author(s) 2020
}

\begin{abstract}
Over the last two decades, we have seen a worldwide expansion of the concept and practice of cultural diplomacy, along with the emergence of a multipolar world. This raises the question of the way in which the notion is mobilized and understood beyond Europe and North America. This paper is based on comparative research carried out in Qatar and Singapore. Both countries have developed ambitious cultural diplomacy strategies, based on the establishment of world-class cultural and educational institutions, and on their integration into regional and global cultural networks. But many have highlighted contradictions between these ambitious strategies and the restrictions and pressures that both countries place on their civil societies. This paper discusses how curators, who have become key global gatekeepers, negotiate their role in their country's global cultural strategy and position themselves with regard to the official national narrative. With their multiple belonging, they shape narratives that make regional and local scenes and can put cities on the world art map. This symbolic power puts them in a strategic position to shape the nation-branding discourse.
\end{abstract}

Keywords Cultural diplomacy · Civil society · Curators · Nation branding · Cultural hubs · Global cities · Qatar · Singapore

\section{Introduction}

Over the last two decades, we have seen a worldwide expansion of the concept and practice of cultural diplomacy, along with the emergence of a multipolar world. This raises the question of the way in which cultural diplomacy is mobilized and understood outside of Europe and North America. In particular, the field has been invested by a wide variety of so-called "emerging countries". Driven by a mounting ambition to make a space for themselves on the world stage,

Jérémie Molho

arijhpm@nus.edu.sg

1 National University of Singapore \& European University Institute, Asia Research Institute \& Robert Schuman Centre for Advanced Studies, Singapore, Singapore 
countries like China, Azerbaijan, Saudi Arabia, and many others have begun to invest heavily in cultural relations, take an active role in multilateral cultural organizations like UNESCO, and launch bilateral cultural cooperation initiatives. But many have highlighted the contradictions between these ambitious strategies and the restrictions and pressures these countries put on their civil societies.

This paper focuses on and compares the cases of Qatar and Singapore. It relies on fieldwork conducted since 2015, and interviews with a wide variety of cultural actors involved in developing international projects and networks. Both Doha and Singapore have developed ambitious cultural diplomacy strategies, based on the establishment of world-class cultural and educational institutions, and on their integration into regional and global cultural networks. The paper relates mainly to one of the two main overarching objectives of this Special Issue, tracing the ways in which civil society actors are involved in countries' cultural diplomacies. It contributes to this reflection not only by analyzing the perspectives of these two ambitious emerging cultural powers but also by focusing on the role of curators, who have risen in the last decades as key gatekeepers in the world's art scenes (Molho 2016).

It is common to conceive civil society as a key factor in countries" "soft power", and much of the literature following the work of Joseph Nye (1990) adopts this instrumental understanding of civil society with regard to states' foreign policy (Melissen 2005). This paper relies on a grounded approach, which traces internal tensions and relations of powers, while recognizing the strong interconnection, and interaction between the national interest and civil society, a relation that needs to be deciphered, rather than just considered as instrumental and unidirectional. It will therefore explore how internationally prominent curators (sometimes referred to as "star curators") negotiate their roles in their country's global cultural strategy and position themselves with regard to the official national narrative.

The paper explores the dialectic tensions that star curators have to negotiate. Curators are navigating between contradictory poles: their allegiance to a global community of cosmopolitan values that establish judgements of their work and condition their star status, and the state bureaucracies that provide the material conditions enabling them to develop their work. How does this configuration translate within emerging city-states with high nation-branding ambitions? What level of autonomy does this allow to these global curators? What possibilities are offered to them to develop transnational cultural relations beyond state-sanctioned and nationally interested rationales? In illiberal contexts, are their initiatives necessarily mere propaganda tools serving to legitimize the dominance of national leaders? In a centralized context, is their discourse necessarily a mere translation of biased and narrow national narratives?

The paper is divided into four sections. In the first section, I discuss notions of cultural diplomacy and civil society as globally circulating scripts, which are put into question due to their active appropriation in illiberal contexts. In the second section, I discuss the evolving role of curators in the global cultural landscape, and how it has been affected by the rising cultural ambitions of emerging countries. The third section introduces Doha and Singapore's top-down strategies to position themselves as cultural hubs, which shape the framework within which cultural diplomacy and civil societies can operate. Finally, I present two prominent curators in both cities and analyze their role in reframing the nation and engaging in the transnational cultural field. 


\section{Cultural Diplomacy and Civil Society: Global Circulation, Local Configuration}

The terms soft power and cultural diplomacy have circulated and been employed in a wide variety of contexts, as scripts that circulate. But this should not be interpreted as a blind replication of Joseph Nye's theory, and it is essential to look into local patterns of appropriations of these concepts and the practices they generate on the ground.

The soft power theory, which has spread throughout the world, has stressed the increasing importance of civil society, presented as instrumental in states' international strategies. Nye (2008: 108) himself argued that "smart public diplomacy requires an understanding ... of the role of civil society in generating soft power". International organizations like UNESCO have promoted civil society and "bottom-up" approaches (Martens 2001). Old cultural diplomacy actors repositioned themselves to give more space for people-to-people cultural relations in the context of mounting suspicions towards state-sponsored approaches (Finn 2003). The new cultural diplomacy tools that have been created in the last three decades all appear to pay particular attention to the mobilization of civil societies.

But this instrumental understanding of civil society for "soft power strategies" does not necessarily go along with the expansion of space for civil society expression. In particular, the use of the soft power script in illiberal and authoritarian contexts constitutes a blow to Nye's liberal theory (Nye 2005). Thirty years after the concept of soft power was coined, it is clear that countries can mobilize culture, people-topeople relations in the pursuit of international influence, without aiming to liberalize civil society. Illiberal or even authoritarian states, like Azerbaijan or China, have not hesitated to mobilize culture as an instrument to raise their geopolitical status (d'Hooghe 2005; Walker 2016). This has generated many debates regarding their objectives. It has often been argued that these initiatives are part of public diplomacy strategies that merely aim at defending the national interest by projecting a positive global image. But many works referring to soft power outside the West have dug insufficiently into the specific dynamics at play in the cultural field. A limited empirical investigation into the dynamics of production of soft power goes along with superficial accounts of the public use of the national culture, to project and testify international influence, often relying on the discourses of state actors rather than on the practices of cultural actors (Angey-Sentuc \& Molho 2015). But studies that have focused upon civil society organizations involved in the development of international cultural relations often show that they have a certain autonomy and capacity to negotiate (Hartig 2012). Indeed, as Isar (2010) argued, "the failure to recognize that cultural actors do not pursue State interest-driven deliverables seems to signal a disjuncture from reality." Therefore, a grounded inquiry is needed, in order to analyze the place of civil societies within illiberal nation-states with high international ambitions. This paper aims to question the capacity of cultural civil society actors to negotiate civic spaces and to challenge national narratives.

Although it seems obvious that civil society is central to cultural diplomacy, to the point of affirming that there would be no genuine cultural diplomacy without civil society, the notion of civil society needs scrutiny. Civil society itself is a broad term that corresponds to a wide variety of actors: from individuals and grassroots organizations to highly institutionalized structures. It is difficult to draw a clear line between what civil society is and what it is not, especially as far as the cultural sector is concerned. Besides, as it is a concept that comes along 
with a certain Western conception of liberal democracy, using the lens of civil society on a global scale carries the risk of adopting a Western-centric point of view that does not fit with local power structures and social dynamics (Lewis 2002; Kaldor 2003).

Identifying "civil society" as opposed to "state actors", or "private actors", is especially difficult in the cultural field, for which an institutionalist approach that would content itself with identifying formal links with state or private actors to determine whether an organization is to be considered as part of civil society seems insufficient. If we take the case of cultural institutes, they are associated with a specific state. The fact that some of these states granted them a relatively autonomous status, of quasi-non-governmental organizations, does not necessarily reduce their image of representing a particular nation-state. What really matters for audiences are the kinds of activities they organize: Are they only promoting national culture through language courses, subsidies to national artists, exhibiting stereotypical aspects of the country's culture, or are they engaging with the local scene in a spirit of mutuality? Do they merely showcase the official national story, or do they explore its complexities?

In sum, this paper does not look at the role of civil society with regard to cultural diplomacy as an instrument to "generate soft power", but rather as an actor susceptible to generate different layers of understanding of national culture. The level of independence of a cultural organization is not to be defined a priori, based on its status and the kinds of funds it receives, but rather a posteriori, based on the nature of its narratives, and the way it relates to the official national narrative. Is it mainly displaying symbols of national pride and consensual moments? Or is it stressing contradictions, tensions, plurality of communities, of views and contentious issues? Is it essentially investing to diffuse national culture, language, heritage, and creations or is it engaging horizontally with international partners?

This present analysis is based on three fieldtrips in Doha and Singapore where I interviewed a wide variety of cultural actors in the public and private sector as well as civil society actors, including cultural agencies, theatres, art galleries, curators, and artists. My argument focuses on star curators. I draw mainly on the interviews I conducted with the director's flagship modern and contemporary art institutions, who are both internationally acclaimed curators, in order to reveal shared perspectives on their role in the nation branding process. I complement this primary interview material with subsequent research on other statements made by these individuals, and also on their initiatives, notably exhibitions.

\section{The Rise of Star Curators and Nation Branding}

The literature on curators discusses their evolving role within the art field, and their wider social role (O'Neill 2007). But we lack systematic investigation on their role as cultural diplomacy actors, in particular in relation to their rising role in a globalized art landscape. The core role of curators is to assemble and display artworks, connecting them through an overarching narrative. Curators are in charge of archiving, collecting, selecting objects, and of organizing the encounter between the public and artworks. In the beginning of the nineteenth century, Dominique Vivant Denon, director of the Napoleon Museum that later on became the Louvre, was a pioneer, as he organized the massive collection plundered by Napoleon's armies in chronological order, and according to national schools. This display not only reflected artistic evolutions and variations across space but also constituted a story that addressed the nation, as well as intellectuals across Europe. Along with the multiplication of 
museums throughout the continent, similar figures gathered objects from across the world, and shaped a cultural discourse to anchor nation-building efforts, combining a nationalist perspective with universalist ideals.

With the rise of modern art movements, exhibitions became increasingly important in defining artistic trends. While initially, avant-garde movements were driven mainly by artists groups and consecrated by art critics, as modern art institutionalizes, the organization of exhibitions making statements about the meaning of art emerges as a professional field. The twentieth century has been marked by a series of "curatorial pioneers" (Obrist et al. 2008), such as Alfred Barr, who became in 1929 the first director of The Museum of Modern Art in New York, as well as Werner Hofmann, who founded Vienna's Museum of the Twentieth Century in 1962.

But it is with the rise of what Nathalie Heinich (2014) has called the "contemporary art paradigm" that the figure of the curator became central. From the 1960s onwards, art discourse started to move beyond the artist and the object to include the exhibition subject, the context, and the role of the curator. In the 1990s, the "curatorial gesture" became an expectation, and the work of curators became a field of critique. This led to the "rise of the curator as creator" (Althshuler 1994). The Swiss curator Harald Szeemann (1933-2005), who revolutionized the format of the Kassel Documenta in 1972, and thereafter repeatedly introduced innovations and transgressions in the ways art is displayed and experienced, largely contributed to affirming the role of the curator as author. In this new paradigm, curators are now expected to develop a singular trajectory. They are less tied to a particular cultural institution than to a transnational cultural field that establishes their reputations.

The rise of star curators appears closely linked to the globalization of the art world. In the 1970s, the push to decolonize the art world, and value subaltern aesthetics, challenged the notion of a universal art history, as had prevailed in modern art (Dossin et al. 2015). The role of art critiques who were in charge of uncovering the linear movement of art history was overtaken by that of curators, who connect different worlds, different visions and definitions of art, and create common meanings among a variety of aesthetics. The multiplication of biennials throughout the world provided a fertile ground for this new approach (Gardner and Green 2016). This paved the way for the rise of nomadic curators mediating different art worlds around common themes and issues (O’Neill 2007). Okwui Enwezor (1963-2019), the New York-based Nigerian curator, who has been credited with placing "non-Western art histories on an equal footing with the long-established narrative of European and North American art" (Basciano 2019), is an emblematic figure of this new kind of curator who has foregrounded the "peripheries" of the global art world.

\section{Curators in "Emerging Nations"}

Curators are key to the ambition of building world-class cultural institutions and have become highly influential within the global cultural field (Meskimmon 2010). The so-called emerging nations, which, over the past three decades, have undergone rapid economic development and demonstrated global ambitions, combine particular conditions that influence the nature of the work of curators. These nations have strong nation-branding ambitions and have created many new cultural institutions. Economic development has not only fuelled their cultural sector with financial resources but also encouraged their leaders to invest in culture as a tool of economic diversification and attractiveness, and to promote the country on the world stage. This situation 
provides curators with new material opportunities: positions in newly created institutions, avenues for international collaborations and networking on their projects, funding to launch their own initiatives such as major international exhibitions. They have been given a mission to provide a cultural narrative underlying their country's economic development.

But more importantly, "emerging" cultural status of these nations fosters a certain postcolonial orientation in these new cultural institutions. Whether they have been former colonies, or have been subject to a form of Western imperialism, these nations consider that they have been marginalized in the global cultural discourse (Molho 2015). Their cultural projects are often conceived as a response to the perception of an imbalance in global cultural power, the sense that in the past, they have either lagged behind, following aesthetic trends established by others, and had to catch up, or in the sense that they have been unfairly represented, and subjected to stereotypes coined by dominant cultural actors. In this context, curators are invested with a mission to contribute to the transgression of dominant and Western-centric aesthetics. The hybrid status of these often wealthy nations in regions that have long been viewed as peripheries in the global art world allows them to claim to be representing "subaltern" voices that have yet to be heard.

These emerging nations are particularly keen on attracting professionals from other countries, or who have had a wide range of experiences in different countries, to the point that many people working in their cultural institutions have studied abroad or are foreigners. As such, they constitute a transnational civil society: they are tied to a specific national institution, but have multiple belongings that shape their action and discourse (Ong 1999). This can result in situations of tensions, and of "professional dissonance" (Harkness \& Levitt 2017), in particular in illiberal contexts where the autonomy and freedom that is associated with their professions enters into conflict with restrictive political regimes.

The local and global reputations of such curators are intertwined. The initiatives they develop locally take part in their affirmation in the global art field, and their global recognition is also a source of influence on the local scene. They belong to two distinct spheres: a national public administration with its bureaucratic hierarchy on the one hand, and a transnational global field, with its hierarchy of prestige on the other. These two spheres are interconnected: their rise on the national bureaucratic hierarchy provides them with resources to establish their influence on a global scale, and the more prestige they acquire on the global art field, the stronger is their legitimacy to diffuse their vision in local institutions.

A series of operations enable curators to exert symbolic power. By presenting their actions as "filling gaps" that exist locally, in the light of international standards, they constitute spheres of relative autonomy. Some of these are the following.

Collecting Curators can take a leading role in acquiring objects for museum collections. As museums institutionalize, the collecting process gets formalized and professionalized, and curating teams guide new acquisitions. They get their legitimacy from their knowledge of the collection and of its gaps.

Documenting One of the core missions of museum curators is to build knowledge on individual artworks and on the whole collection. With the rise of new technologies, museums also build online platforms that visualize collections and provide background knowledge. They fill gaps by identifying missing or biased knowledge.

Narrating Curators relate artworks to history, context, and international artistic movements. They highlight key characters. Exhibitions have become narrative experiences. Beyond 
providing information on artworks, they offer multisensorial, journeys, with different steps illuminated by the artworks.

Networking Museums do not operate in a vacuum but are nodes within a complex network. By creating regional networks, they can join forces with other museums to challenge dominant narratives. They also develop local networks with the local artistic milieu to support creation and education.

\section{Doha and Singapore's Cultural Hub Strategies}

In 2018, Rosa Daniel, the CEO of Singapore's National Arts Council, affirmed that the citystate "aspires to become a global cultural hub". Likewise, Doha's cultural policy wing, Qatar Museums, refers explicitly to its objective to mobilize its educational and cultural programmes in order to "enhance Qatar's status as a cultural hub in the world" (Qatar News Agency 2016). Doha and Singapore converge in their mobilization of the notion of "cultural hub" to capture their cultural strategy. This strategy derives not only from their particular situation of citystates that need to connect to their region and to the world but also from the wider dialectic that cultural diplomacies have to negotiate, between national promotion and global engagement.

Cultural hub strategies are coherent with both countries' foreign policy approaches as small and vulnerable states in tense regional environments (Ganesan 2005; Cooper and Momani 2011). They have had multiple conflicts with their neighbours, despite having a lot in common and a high level of interdependence with them. They have been very active in pushing forward regional integration mechanisms as soft cooperation tools. These cultural hub strategies thus derive from these particular geographic and geopolitical configurations, the willingness to promote peaceful relationships with their regional neighbourhoods and diversify alliances to gain autonomy.

Cultural hub strategies can also be related to Doha and Singapore's positioning as "global cities", and the application to the cultural field of an economic strategy that combines competition and cooperation on regional and global scales. Both cities like to stress the long way path they have travelled during the second half of the twentieth century, with Doha stressing that earlier, it was no more than a "small fishing port", and Singapore asserting that it used to be viewed as a "third world country". In fact, today, Singapore usually reaches the top of flourishing global city rankings, whereas Doha, which is only second to its regional rival Dubai, remains a strong contestant in this staged global competition. Both Doha and Singapore have created new cultural infrastructure such as museums, art schools, and biennials, with a specific regional focus intended to affirm regional hub status. The Vision 2030 plan in Doha and the Renaissance City Plan in Singapore reflects both city-states' ambition to use culture as a central part of their social and economic development. Both cities have also invested in the construction of world-class museums, such as the Singapore Art Museum (in 1996) and the National Gallery Singapore (in 2015), as well as Doha's Museum of Islamic Art (in 2008) and Mathaf (in 2010) (Levitt 2015). These strategies have shaped the urban landscape, with the establishment of dedicated districts such as Education City and Katara in Doha, or the Gillman Barracks art district in Singapore.

Despite the impression of openness associated with such cultural hub strategies, this remains a tightly controlled and highly nationalistic approach: the notion of global city in these contexts is not to be equated with a post-national model. Globalization has often been 
associated with a decline of the nation-state and global cities, as symbols, catalysts, and nodes of global processes have been viewed as a challenge to the post-Westphalian notions of sovereignty and citizenship (Sassen 1991; Holston 1999). However, the return of the nation is now tangible in different parts of the world, with the rise of populist rhetoric and of bellicose rivalry (Triandafyllidou 2017). The city has emerged as a space of affirmation of the national, of projection of an imagined national identity, which conveys local and international interests. This is particularly true in the cases of Doha and Singapore, where as it has been argued, global city formation goes along with a developmentalist model, with strong state intervention in all spheres of the economy and society (Bunnell 2002; Olds and Yeung 2004).

These considerations are essential to analyze the level of autonomy of civil society. In Doha, a traditional form of civic space, the majlis, enables a semi-public expression of opinions, while formal political organizations are banned, dissent is repressed and press freedom is highly restricted (Babar 2014; Ulrichsen 2014). In Singapore, despite the presence of formal civil society organizations that fit into a tight framework established by the state, there are numerous laws, regulations, and repressive practices which put limits on civil society initiatives (Nasir and Turner 2013).

While the framework within which they are able to operate remains restricted, civil societies are essential to Doha and Singapore's ambition to position themselves as cultural hubs, to integrate the global cultural sphere, and to develop regional networks. Both strive to project the image of a dynamic civil society. In Doha, in the context of the blockade initiated by the UAE and Saudi Arabia, multiple expressions of support have been displayed in public spaces, and in various cultural and educational institutions, in the forms of panels on which people can write short notes. The city has hosted a number of Arab activists persecuted in their countries and has given them international exposure. The Msheireb museum inaugurated in 2015 displayed many interviews with ordinary citizens to explore their memories, including those of the descendants of African slaves who have been the object of various forms of discrimination. As for Singapore, the 2012 Arts and Culture Strategic Review officially stated the importance of giving more space to civil society in the elaboration of cultural policies, which had so far been dominated by a top-down approach. This translated into an increase in subsidies to cultural NGOs. The city-state is also keen to distinguish and celebrate cultural civil society figures such as artists and cultural managers. Numerous prizes have been created and their portraits and achievements are often displayed in cultural institutions like the Esplanade. In this context, curators in Doha and Singapore have played a strong role in the promotion of the nation in cosmopolitan terms. They narrate their city as a cultural hub, as a cradle of innovation, as a centre of the avant-garde (Verhoeff and Wilmott 2016). They situate it as embedded within regional networks and in a series of imaginary transnational communities (Gardner and Green 2016).

\section{Curators and Scene Making in Doha and Singapore}

This section explores the trajectory, practice, and discourse of two prominent curators in Singapore and Doha, who lead their city's major cultural institution and are charged with projecting the image of their city as a cultural hub. ${ }^{1}$

\footnotetext{
${ }^{1}$ Unless specified otherwise, the citations in this section are drawn from interviews that I conducted with Abdellah Karroum in January 2018 in Doha and with Eugene Tan in December 2018 in Singapore.
} 
Abdellah Karroum is the director of Mathaf (Doha's modern and contemporary art museum) since 2013. He is Moroccan and studied in France. He did a PhD in Bordeaux and worked for the city's Contemporary Art Museum. While still in France, he established a publishing house named Hors Champs. This enabled him to start engaging with intellectual and artistic movements in his home country. Then, he came back to Morocco where he first set up artistic expeditions, before opening, in 2002, an experimental art space in Rabat, the Apartment 22. This artist residency and exhibition space responded to a need in the local scene for a space to show contemporary creation.

In the 2000s, he engaged with various emerging art scenes from the Southern hemisphere. He curated major international exhibitions, like the 2006 DAK'ART Biennial for African Contemporary Art and the 2009 AiM Marrakech Biennale. In 2010, he was invited to Colombia and experimented with the notion of "curatorial delegation", which he put forward as "a methodology that helps a curatorial group to understand a context and to produce an exhibition or a publication ... led by the person who knows the context"(Alessandrini 2017). He used this approach in 2012 as artistic director of the Biennale of Benin. He also collaborated with a number of European Institutions. He curated the Paris Triennale in 2012, as well as a multi-stage project that took place at La Kunsthalle in Mulhouse in 2013 and at MACBA in Barcelona in 2014. He took part in the Golden Lion Jury in the Biennale of Venice in 2007, the Prince Pierre Monaco Foundation's International Prize of Contemporary Art committee, and the acquisitions committee of the FRAC PACA collection in Marseille.

He joined Mathaf in 2013. Karroum brings a contemporary art perspective to a museum initially thought of as a modern collection. He has stated:

I think their interest in me was on that side, the relation between art and society, art and politics. Al Mayassa [The head of Qatar Museums] studied political science and art history, so I think we had common interest about art as a tool of development, art as a tool for education, a space of communication, of dialogue and debate within the society.

In 2014, Karroum dedicated the first floor to the permanent collection. He created a project space for experimental curatorial practice and emerging artists. He curated exhibitions of Mathaf's permanent collection, as well as solo exhibitions like Farid Belkahia in 2015 and Shakir Hassan Al-Said in 2017. He has continued to regularly run exhibitions in Rabat, like that of Younes Rahmoun in 2016, as well as exhibitions of Arab artists in Europe, like "Wael Shawky, Al Araba Al Madfuna" at the Fondazione Merz, in Turin, and "Looking at the World Around You", displaying works from Qatar Museums, at the Santander Foundation in Madrid, in 2016.

Eugene Tan has been director of the National Gallery of Singapore since 2013 and was appointed in 2019 as director of the Singapore Art Museum as well. He has a $\mathrm{PhD}$ in Art History from the University of Manchester. He became director of the Institute of Contemporary Art upon his return to Singapore and was also director of Sotheby's Institute of Art in Singapore. He was the curator of Singapore's first pavilion at the Venice Biennale in 2005. The next year, he co-curated the first Singapore Biennale. He settled for a couple of years in Hong Kong as director of exhibitions for the Osage Gallery. In 2010, the Singapore Economic Development Board called him back to Singapore to oversee the creation of the Gillman Barracks art district. Three years later, he was appointed as director of the National Gallery, which opened its door in 2015.

While the gallery's focus both on Singapore and on Southeast Asia's art histories was "more or less decided before (he) joined", he took the position because it was in line with his 
long-standing ambition to connect the Southeast Asian Art scene with the global art discourse; as he puts it:

When I first returned to Singapore in 2004, a lot of the discussions about the region, or art in the region, were very much happening within the region. It was a very insular kind of discourse that was happening with people in Southeast Asia, and to a certain extent by some people in Japan and Australia - very limited I think. And what was really absent was how this discourse connected with the larger global discourse about art. And to an extent, I helped facilitate that.

He also relates his stay in Hong Kong with his ambition to promote Southeast Asian art on the global art stage: "I saw this as a good opportunity to increase the platforms to the Southeast Asian artists to show, and increase the dialogue between Southeast Asia and other parts of Asia." His international stature took off after he became the head of the ambitious Gillman Barracks project. He was included in the famous Art Review's Power 100 that lists influential actors in the global art world. Through the Gillman Barracks cluster, he contributed to fill gaps in the local scene, responding to a need for high-profile international galleries, an international centre for curatorial research, and an international artist residence programme. As director of the National Gallery, he led exhibitions such as "Reframing Modernism: Painting from Southeast Asia, Europe and Beyond" (2016), Yayoi Kusama's "Life is the Heart of a Rainbow" (2017), and "Minimalism: Space. Light. Object" (2018-2019).

These two cultural leaders share some characteristics. They are both contemporary art curators leading modern art institutions. They have international profiles and are integrated into global networks. They both express a need to "fill gaps" in their local art scene, stepping up art education, taking an active role in the art ecosystem, revisiting art history, and expanding the museum's collection.

\section{Building a Regional Collection, Pushing the Boundaries}

Curators have a key role in expanding museums' collections, building on their understanding of their "gaps". Purchasing decisions are in the hands of an acquisition committee - in Qatar, of particular members of the royal family. But these decisions are informed by curators' work. Their role is to identify missing knowledge. Mathaf has an immense collection initially assembled by a member of the royal family, Hassan Al Thani. The Mathaf team has worked to rationalize the collecting process:

The first collection was made out of passion. So you have major groups of artists, but you find gaps, because artists who were not interesting for the group of people who were choosing the works are missing in the collection. So our challenge was to study and survey what we have. With the curatorial team, we are making a timeline to analyse what the collection is and where the gaps are. We know that there are some productions at a certain moments in relation with what is happening in the society. There are some important political events that happened and some responses by artists. But if we didn't have it in the collection, we have to find out and buy.

Karroum refers to specific periods for which the collection lacks artworks, like the time before the Arab spring. He also argues that the collection is lacking artworks from some parts of the Middle East such as Turkey and Iran. Despite the objective of the museum to "give value, 
historical value to the artists from this region", there is a relatively loose definition of the collection's boundaries.

The collection of the museum is dedicated to what we call North Africa and Middle East, or the large geography of the Arab world, precisely, from Turkey to Soudan and from morocco to Iran; and its historical and cultural connections. When you say historical and cultural connections, you go to Pakistan, to India, to Southeast Asia. Cultural connections means exchanges as well historical trade. We have artists from Soudan, China. You add on the diaspora, artists who emigrated, who were for example from North Africa and emigrated to Europe, third or second generations.

The Singapore National Gallery's collection was initiated in the 1970s through a public acquisition policy and fed by purchases and donations. Out of the 8000 works in the collection, about $70 \%$ are from Singapore and $30 \%$ by Southeast Asian artists. As Eugene Tan explains, new acquisitions are "first and foremost identified and proposed by curators", in order to identify works that are significant from the point of view of art history, and are representative of the artistic practices of the region. "Our curators are always doing research into areas that we feel we are still lacking in knowledge, trying to uncover new knowledge". To collect on a regional scale, they benefit from a highly international team: "we have curators from all over the region: from Malaysia, from the Philippines, Indonesia, etc. And they specialize on at least two countries each, which then allows us to have a comprehensive perspective on the region".

Compared with Mathaf, there is a more clear-cut definition of the regional boundaries of what the museum focuses upon. Yet, Tan stresses that "Southeast Asia itself is contested", and as a result, an object of questioning and reflections: "our curators are also thinking historically, what are the links between the countries in the region and also beyond the region, what do we mean by Southeast Asia, so India and China, are kind of the boundaries we are exploring".

\section{Decolonising Art History}

The mission of these curators to produce documented knowledge on the art of their regions takes on a particular meaning in the Middle East and Southeast Asia, where art knowledge has for long been dominated by an orientalist vision. Thus, building knowledge on individual artworks and on museum collections also means coping with what colonization led to, namely, a partial, biased vision of the region's art production, along with an exoticizing gaze on the region's societies.

Mathaf has often been presented as the first pan-Arab museum of modern and contemporary art. For a long time, cultural pan-Arabism was mainly showcased in institutions located outside of the Arab world. Numerous organizations were created in Europe to support and promote Arab art: from the Arab British Centre in London (1977) to the Institut du Monde Arabe in Paris (1987), and the Casa Arabe in Madrid and Cordoba (2006). Meanwhile, most modern art museums in the Arab world were focusing on their national culture, like the Egyptian Modern Art Museum in Cairo. Therefore, Doha was a pioneer in this regard: it did not restrict to its national scene, but went beyond it. Nada Shabout, who was an advisor for the Mathaf project and curated one of its first temporary exhibitions, argued that "Mathaf is an Arab perspective on modernity" (Ayad 2011).

In 2014, Abdellah Karroum launched an Encyclopaedia of modern art in the Arab world at Mathaf, which provides a chronological overview of Arab artists from the nineteenth century to the present. Karroum explains that this project "looks at modern 
art and its histories, its multiple histories, in connexion with what you call modern art in general: what is universal and what is specific to a place?" Through his exhibition of the permanent collection, Karroum affirms that the "Museum's role is not only to conserve art over time, but to suggest paths for revisiting, re-experiencing, and seeing the selected artworks in light of current events and curatorial readings" (Mathaf 2015). To do so, his exhibition invites to rethink "art history and its connection to the world through original research, writing, and curating". Departing from a vision that views artists from the region as mere imitators of global art movements, the exhibition, which focuses on different artists of the region, Farid Belkahia (Morocco), Saloua Raouda Choucair (Lebanon), Faraj Daham (Qatar), Inji Efflatoun (Egypt), Abdelhalim Radwi (Saudi Arabia), stresses their "original yet universal creations", describing how they have been "generating ideas and inventing techniques as they, in conversation with international art movements and other geographies, make sense of their artistic, social, and political worlds" (Ibid.).

To achieve this objective, the curatorial team engages with other artistic institutions, to promote their alternative visions. For instance, the temporary exhibition "Tea with Nefertiti" travelled to Munich, Paris, and Valencia between 2013 and 2014. This exhibition "revisits the contested histories of how Egyptian collections have been amassed by numerous museums from the 19th century onwards" (Mathaf 2013). At the end of the 2010s, Mathaf collaborated with Haus der Kunst, Munich, Kunstmuseum Bern, and Guggenheim Bilbao to set up an exhibition of the prominent Ghanaian artist El Anatsui.

When the Singapore National Gallery opened, Eugene Tan argued that "the history of Southeast Asian art has been absent from the world, which is why [he] think[s] [they are] doing here is so important in presenting this art history from a regional perspective through a long term extensive exhibition" (Binlot 2015). Exhibition after exhibition, the museum and its curatorial team strived to correct this bias: by uncovering the art history of the region and establishing links with cultural institutions in other countries. In 2016, the gallery collaborated with the Centre Pompidou in Paris to set up an exhibition on the Malaysian artist Latiff Mohidin, in order to "reframe modernism" and "contribute to a more nuanced understanding of interactions between Southeast Asia and Euro-America from a decentralised perspective" (Singapore National Gallery 2016a). Tan explains: "This is part of our mission to promote Southeast Asian artists around the world".

The same year, the gallery put together a show named "Awakenings" on three figures of the 1970s Johnny Manahan (The Philippines), Redza Piyadasa (Malaysia), and Tan Teng-Kee (Malaysia/Singapore) working with new media who "broke new ground in Southeast Asian modern art, challenging the boundaries of painting, sculpture, photography, video, and performance"(Singapore National Gallery 2016b). The show was co-curated with the Museum of Modern Art in Tokyo and a museum of modern and contemporary art in Seoul and it toured the three cities. Such collaborative curatorial work can uncover transnational connections that have not been considered in art history, as Tan explains:

This was art where artists saw the role of art to transform society; so art as a kind of activism, and all these practices, because they were not really collectible, they were written off the art market, and because Asia, in the past few decades, has really been dominated by the art market, this area just kind of got overlooked, but we feel it is important to emphasize this as part of our history as well. 


\section{Storytelling and Regional Framing}

Both Mathaf and the Singapore National Gallery have developed regional collections and put forward regional narratives, unifying diverse creations around a common story. This regional outlook has been integrated into a nation-building discourse at the same time.

Thus, the Singapore National Gallery has two main permanent exhibitions: a Singaporean art exhibition and a Southeast Asian art exhibition. The latter contains 400 artworks from Indonesia, the Philippines, Vietnam, Malaysia, Thailand, Cambodia, Singapore, Myanmar, Laos, and Brunei. Going back to the nineteenth century, it reflects commonalities across Southeast Asia, including parallel colonization and Cold War histories: "Its aim is to provide a sense of the richness and diversity of the art in Southeast Asia through shared historical experiences, highlighting the key impulses to art making across the region" (Tan 2015). The exhibition specifically focused on Singapore's art history, reflects its transnational character. The exhibition stresses the international mobility of Singaporean artists, and their intense relations and aesthetic connections with the region.

According to Sultan Sooud Al-Qassemi (2013), an influential Bahraini art patron, Mathaf reflects common experiences throughout the Arab world:

Mathaf's artistic frontiers stretch the width of the Arab world from Morocco to the Gulf and include artworks by diaspora Arabs who have often been neglected for political or geographical reasons. Mathaf's pan-Arab collection demonstrates that the struggles of Algerians and Iraqis, Palestinians and Yemenis as depicted by Arab artists blend together seamlessly as though pieces of a giant puzzle have finally started to fall into place.

Al Qassemi also argues that artists can build connections where politicians have been unable to construct unity, and artists draw on an existing sense of belonging, and celebrate transnational causes, like the Palestinian struggle. In fact, the artworks in the permanent collection of Mathaf contain many references to political issues, events, and crises that have marked the history of the Arab world. In 2018, Karroum curated "Revolutions Generation" presenting artists from the Arab world, Turkey, Iran, and the diaspora, and going back into key moments in the region's modern and contemporary art history. The exhibition showed how "underground artistic movements developed in the region in response to the absence of freedom of expression" (Mathaf 2018) and stressed the role of artists "as vital actors of social and cultural change" (Ibid.).

Nevertheless, this hopeful regional framing, which projects the idea of a unified region, contrasts with the reality of divisions, which constitute concrete obstacles to the actual development of regional networks and interactions. Geopolitical fragmentation is particularly evident in Qatar, as the country has been cut off from its immediate neighbourhood for years, since the start of the so-called Gulf Crisis in 2017. This blockade has seriously constrained cultural exchanges and prevents synergies between the ambitious cultural policies launched in different parts of the region. Another key hurdle to the intensification of cultural interactions is the high level of inequality in terms of cultural infrastructure. For example, Singapore's National Gallery is obliged to collaborate with private foundations in countries like Malaysia and Indonesia, owing to the lack of professionalism of public institutions and the capacity to handle artworks securely in those countries. 


\section{Conclusion}

Instead of defining civil society as a separate sphere, I have considered it as part of a system, which involves state actors and private actors. As for cultural diplomacy, regardless of whether it is understood as a projection of a country's culture and values on the world stage, or as an enterprise of intercultural exchange, the practice always involves more than the state. The role of civil society in cultural diplomacy poses questions beyond that of which actors are involved and includes the question of how they stand with regard to the official national narrative.

The experience of Doha and Singapore suggests that the ambitions of both cities to become cultural hubs lead to an empowerment of transnational civil society. On the one hand, transnational professionals with multiple identities and belongings take on a larger role in the elaboration of cultural diplomacies. The crucial roles of transnational actors in the transformation of these cities as cultural hubs afford them a certain autonomy in developing a more sophisticated national narrative, which includes a pluralist and transnational perspective, while remaining within the general framework set by state actors. Transnational cultural civil society actors, who operate within the framework of national cultural institutions that have vertically defined missions to project fixed national identities, can nevertheless draw on their global prestige to promote a more plural and complex vision of national culture. On the other hand, despite being run by illiberal governments that do not hesitate to censor dissenting opinions and cultural expressions, these cities constitute centres of expression of regional issues. Civil society actors attempt to negotiate degrees of cultural freedom within tightly controlled systems, by mobilizing transnational cultural networks, dealing with regional issues and global topics. Both Southeast Asia and the Arabian Gulf curators are constructing place-specific narratives, which draw on local resources: for Singapore, the proximity of Southeast Asia, along with the historical transnational connections to other countries like India and China; for Doha, the Arabian Gulf, the Arab world, and the Middle East more generally. Star curators enjoy varying degrees of autonomy, sometimes adopting frames from the national narrative and conferring them with new meanings, or expanding existing frames towards new horizons. This role-play between state bureaucracies and star curators, charged with this worldmaking mission, generates new types of national-transnational entanglements, and identity assemblages.

Funding This work was supported by the H2020 Marie Skłodowska-Curie Actions [843269]. Open access funding provided by European University Institute - Fiesole within the CRUI-CARE Agreement.

Open Access This article is licensed under a Creative Commons Attribution 4.0 International License, which permits use, sharing, adaptation, distribution and reproduction in any medium or format, as long as you give appropriate credit to the original author(s) and the source, provide a link to the Creative Commons licence, and indicate if changes were made. The images or other third party material in this article are included in the article's Creative Commons licence, unless indicated otherwise in a credit line to the material. If material is not included in the article's Creative Commons licence and your intended use is not permitted by statutory regulation or exceeds the permitted use, you will need to obtain permission directly from the copyright holder. To view a copy of this licence, visit http://creativecommons.org/licenses/by/4.0/. 


\section{References}

Alessandrini, M. (2017). 'Abdellah Karroum, director of Mathaf Museum, Doha, Qatar', Radicate http://www. radicate.eu/conversation-with-abdellah-karroum-director-of-mathaf-doha-qatar/. Accessed date $29 \mathrm{Apr}$ 2020.

Al-Qassemi, S. S. (2013)."The Arab Museum of Modern Art in Qatar can Mathaf restore a Pan-Arab artistic identity?" Qantara.de https://en.qantara.de/content/the-arab-museum-of-modern-art-in-qatar-can-mathafrestore-a-pan-arab-artistic-identity. Accessed date 24 Feb 2020.

Althshuler, B. (1994). The Avant-Garde in Exhibition: New Art in the 20th Century, New York, Harry N. Abrams.

Angey-Sentuc, G., \& Molho, J. (2015). A critical approach to soft power: grasping contemporary Turkey's influence in the world. European Journal of Turkish Studies Social Sciences on Contemporary Turkey, 21.

Ayad, M. (2011). Arriving at history - Mathaf: Arab Museum Of Modern Art, Canvass: Art and culture from the Middle East and Arab World P. 86.

Babar, Z. R. (2014). The cost of belonging: citizenship construction in the state of Qatar. The Middle East Journal, 68(3), 403-420.

Basciano, O. (2019). "Okwui Enwezor: the Nigerian who confronted the European art canon" The Guardian, 22 Mar 2019 https://www.theguardian.com/artanddesign/2019/mar/22/okwui-enwezor-nigerian-curatorconfronted-european-art. Accessed date 23 Mar 2020.

Binlot, A. (2015). The National Gallery Singapore Opens, Exposing the world to Southeast Asian Art Forbes Dec 28, 2015 https://www.forbes.com/sites/abinlot/2015/12/28/the-national-gallery-singapore-opensexposing-the-world-to-southeast-asian-art/\#5d6561e04787.

Bunnell, T. (2002). Cities for nations? Examining the city-nation-state relation in information age Malaysia. International Journal of Urban and Regional Research, 26(2), 284-298.

Cooper, A. F., \& Momani, B. (2011). Qatar and expanded contours of small state diplomacy. The International Spectator, 46(3), 113-128.

d'Hooghe, I. (2005). Public diplomacy in the People's Republic of China. In The new public diplomacy (pp. 88105). Palgrave Macmillan, London, Public Diplomacy in the People's Republic of China.

Dossin, C., Joyeux-Prunel, B., \& Kaufmann, T. D. (Eds.). (2015). Circulations in the global history of art. Ashgate Publishing, Ltd.

Finn, H. K. (2003). The case for cultural diplomacy: engaging foreign audiences. Foreign Affairs, 82, 15-20.

Ganesan, N. (2005). Realism and interdependence in Singapore's foreign policy. Routledge.

Gardner, A., \& Green, C. (2016). Biennials, triennials, and documenta: the exhibitions that created contemporary art. Wiley.

Harkness, G., \& Levitt, P. (2017). Professional dissonance: Reconciling occupational culture and authoritarianism in Qatar's universities and museums. Sociology of Development, 3(3), 232-251.

Hartig, F. (2012). Cultural diplomacy with Chinese characteristics: the case of Confucius Institutes in Australia. Communication, Politics \& Culture, 45(2), 256.

Heinich, N. (2014). Le paradigme de l'art contemporain. Structures d'une révolution artistique. Gallimard.

Holston, J. (1999). Cities and citizenship. Duke University Press.

Isar, Y. R. (2010). Cultural diplomacy: an overplayed hand? Public diplomacy magazine, 3, 29-44.

Kaldor, M. (2003). The idea of global civil society. International Affairs, 79(3), 583-593.

Levitt, P. (2015). Artifacts and allegiances: how museums put the nation and the world on display. Univ of California Press.

Lewis, D. (2002). Civil society in African contexts: Reflections on the usefulness of a concept. Development and change, 33(4), 569-586.

Martens, K. (2001). Non-governmental organisations as corporatist mediator? An analysis of NGOs in the UNESCO system. Global Society, 15(4), 387-404.

Mathaf (2013). « Tea with Nefertiti » Exhibition statement http://www.mathaf.org.qa/en/tea-with-nefertiti. Accessed date 25 Feb 2020.

Mathaf (2015). « Focus: Works from Mathaf collection » Exhibition statement http://www.mathaf.org. qa/en/focus. Accessed date 25 Feb 2020.

Mathaf (2018). "Revolution generations" Exhibition Statement http://www.mathaf.org.qa/en/revolutiongenerations. Accessed date 23 Mar 2020.

Melissen, J. (2005). Wielding soft power: the new public diplomacy (p. 4). Netherlands: Netherlands Institute of International Relations, Clingendael.

Meskimmon, M. (2010). Contemporary art and the cosmopolitan imagination. Routledge.

Molho, J. (2015). The soft power of framing: constructing Istanbul as a regional art centre. European Journal of Turkish Studies. Social Sciences on Contemporary Turkey, 21. 
Molho, J. (2016). Mise aux normes et promotion internationale de la scène artistique d'Istanbul: l'émergence d'un système galeriste-curateur. Anatoli. De l'Adriatique à la Caspienne. Territoires, Politique, Sociétés, 7, 83-95.

Nasir, K. M., \& Turner, B. S. (2013). Governing as gardening: reflections on soft authoritarianism in Singapore. Citizenship Studies, 17(3-4), 339-352.

Nye, J. S. (1990). Soft power. Foreign Policy, 80, 153-171.

Nye, J. S. (2005). The rise of China's soft power. Wall Street Journal Asia, 29(6), 8.

Nye, J. S. (2008). Public diplomacy and soft power. The Annals of the American Academy of Political and Social Science, 616(1), 94-109.

O'Neill, P. (2007). The curatorial turn: from practice to discourse. In. Rugg, J., \& Sedgwick, M. (Eds.). (2007). Issues in curating contemporary art and performance. Intellect Books, 13-28.

Obrist, H. U., Bovier, L., \& Theiler, B. (2008). A brief history of curating. Zurique: JRP/Ringier.

Olds, K., \& Yeung, H. (2004). Pathways to global city formation: a view from the developmental city-state of Singapore. Review of International Political Economy, 11(3), 489-521.

Ong, A. (1999). Flexible citizenship: the cultural logics of transnationality. Durham: Duke University Press.

Qatar News Agency. (2016). Qatar's status grows as a cultural hub of world Gulf Times December 082016 https:/www.gulf-times.com/story/523982/Qatar-s-status-grows-as-a-cultural-hub-of-world. Accesssed date 05 Jan 2020.

Sassen, S. (1991). The global city: New York, London, Tokyo. New York: Princeton University Press.

Singapore National Gallery. (2016a). « Reframing modernism » Exhibition Catalogue.

Singapore National Gallery. (2016b). Exhibition statement: «A Fact Has No Appearance: Art Beyond the Object » https://www.nationalgallery.sg/see-do/programme-detail/88/a-fact-has-no-appearance-art-beyond-theobject. Accesssed date 20 Nov 2020.

Tan, E. (2015). "Re-writing a National Art History: National Gallery Singapore" https://www.mccy.gov.sg//media/Mccy-Ca/Feature/Resources/Journals/Cultural-Connections-Vol-1/5-Dr-Eugene-Tan.pdf. Accesssed date 05 May 2020.

Triandafyllidou, A. (2017). The return of the national in a mobile world. In A. Triandafyllidou (Ed.), Multicultural Governance in a Mobile World (p. 19). Edinburgh University press.

Ulrichsen, K. C. (2014). Qatar and the Arab spring. Oxford University Press.

Verhoeff, N., \& Wilmott, C. (2016). Curating the city: urban interfaces and locative media as experimental platforms for cultural data. Code and the city, 116.

Walker, C. (2016). The hijacking of "soft power". Journal of Democracy, 27(1), 49-63.

Publisher's Note Springer Nature remains neutral with regard to jurisdictional claims in published maps and institutional affiliations. 